\title{
ZACHOWANIA ZDROWOTNE OSÓB STARSZYCH POWIATU DĘBICKIEGO
}

\author{
HEALTH BEHAVIORS OF THE ELDERLY IN THE DĘBICA POVIAT \\ Monika Łabuzek', Aneta Grochowska', Kazimiera Moździerz', Wioletta Wstawska² \\ 'Zakład Pielęgniarstwa, Instytut Ochrony Zdrowia, Państwowa Wyższa Szkoła Zawodowa w Tarnowie \\ ${ }^{2}$ Zespół Opieki Zdrowotnej w Dębicy, Oddział Anestezjologii i Intensywnej Terapii Państwowa Wyższa Szkoła Zawodowa w Tarnowie, Zakład Pielęgniarstwa \\ DOI: https://doi.org/10.20883/ppnoz.2019.23
}

\section{STRESZCZENIE}

Wstęp. Przestrzeganie zachowań zdrowotnych ma istotny wpływ na proces starzenia się człowieka, gdyż zapewnia zachowanie autonomii w codziennym funkcjonowaniu. Na dobry stan zdrowia wpływa uregulowany tryb życia, zbilansowana dieta, aktywność fizyczna oraz prawidłowy sen i odpoczynek.

Cel. Celem pracy była analiza zachowań zdrowotnych osób starszych w powiecie dębickim.

Materiał i metody. Badania przeprowadzono wśród 140 mieszkańców powiatu dębickiego w okresie od marca do kwietnia 2016 r. W przeprowadzonych badaniach posłużono się metodą sondażu diagnostycznego. Jako narzędzia badawczego użyto autorskiego kwestionariusza ankiety oraz Inwentarza Zachowań Zdrowotnych Z. Juczyńskiego. Weryfikacji różnic między zmiennymi dokonano testem Manna-Whitneya oraz testem Kruskala-Wallisa. Przyjęto poziom istotności $p<0,05$. Obliczenia przeprowadzono programem SPSS.

Wyniki. Wśród badanych znalazło się nieznacznie więcej kobiet (54,3\%) niż mężczyzn (45,7\%). Średni poziom nasilenia zachowań zdrowotnych wyniósł 86,89 pkt., na tej podstawie można stwierdzić, że nasilenie zachowań zdrowotnych wśród badanej grupy było powyżej poziomu przeciętnego. Zdrowego stylu życia starało się przestrzegać 42,9\% badanych, natomiast 12,9\% zadeklarowało nie przestrzeganie zasad zdrowego stylu życia.

Wnioski. Badania wykazały, że najbardziej nasilone u osób starszych są zachowania profilaktyczne, następne miejsce kolejno zajmują pozytywne nastawienie psychiczne i praktyki zdrowotne, a najmniej nasilone są praktyki żywieniowe. Osoby z wyższym wykształceniem, kobiety oraz osoby mieszkające w mieście prezentują wyższy poziom nasilenia zachowań zdrowotnych. Wiek badanych nie ma wpływu na przestrzeganie zachowań zdrowotnych. Status materialny ma istotny wpływ na zachowania profilaktyczne i pozytywne nastawienie psychiczne osób badanych. Osoby starające się przestrzegać zdrowego stylu życia, w tym także zasad prawidłowego żywienia, mają wyższy wskaźnik nasilenia zachowań zdrowotnych.

Słowa kluczowe: zdrowie, zachowania zdrowotne, osoby starsze.

ABSTRACT

Introduction. Compliance with health behaviors significantly impacts the process of aging as it ensures maintaining autonomy in everyday functioning Well-being is affected by a regulated lifestyle, a balanced diet as well as physical activity and proper sleep and Rest.

Aim. The objective of the study was to analyze health behaviors of older people in the Dębica county.

Material and methods. The studies were conducted among 140 residents of the Dębica county in the period from march to april 2016. In the conducted studies the method of a diagnostic survey was applied; an original questionnaire and the Inventory of Health Behaviors of Z. Juczyński were used as study tools. The Mann-Whitney's test and the Kruskal-Wallis test were used to verify differences between the variables. The significance level was assumed as $p<0.05$. Calculations were conducted using the SPSS program.

Results. The study group consists of slightly more women (54.3\%) than men (45.7\%). The average level of intensity of health behaviors was 86.89 points; on its basis it could be stated that intensity of health behaviors among the study group was above average. $42.9 \%$ of the people from the study group tried to maintain a healthy lifestyle, while $12.9 \%$ declared that they failed to follow healthy lifestyle principles.

Conclusions. The studies indicated that preventive behaviors are most intense in older people, and then the following places are taken by positive mental attitude and health practices, Chile dietary practices are least intense. People with higher education, women and people living in the city indicate a higher level of intensity of health behaviors. The age of the study group does not impact following health behaviors. Material status has a significant impact on preventive behaviors and positive mental attitude of the study group. People trying to follow principles of a healthy lifestyle, including principles of proper diet, have a higher ratio of intensity of health behaviors.

Keywords: health, health behavior, elderly person.

\section{Wstęp}

Zdrowie jako pojęcie analizowane może być na wielu płaszczyznach naukowych, zazwyczaj dotyczy ono medycyny, psychologii, a także socjologii. Na każdej płaszczyźnie zdrowie uznawane jest za wartość indywidualną oraz społeczną. W obecnym czasie problem zdrowego stylu życia zyskał specjalne znaczenie, ponieważ to właśnie zachowania zdrowotne warunkują utrzymanie, a także wzmacnianie zdrowia zarówno indywidualnego, jak również całej populacji. Każdy okres życia, również późna dorosłość, umożliwia sprostanie wyznaczonym zadaniom rozwojowym, w przypadku ich niewypełnienia 
wraz z wiekiem skutkuje to frustracją, jak również negatywnie zabarwia obraz starości [1, 2].

Styl życia i związane z nim zachowania zdrowotne należą do najważniejszych czynników, które warunkują zdrowie. W starości zdrowie głównie zależy od odpowiedniego odżywiania, profilaktyki schorzeń cywilizacyjnych, aktywności fizycznej oraz zdrowego środowiska naturalnego i umiejętności radzenia sobie w sytuacjach stresowych. Pomimo tego, że proces starzenia się jest nieuchronny można mieć wpływ na zachowanie sprawności psychofizycznej, a także niezależności. Konieczna jest także akceptacja zmian wynikających ze starzenia się oraz powiększających się ograniczeń. Należy zaakceptować naturalne i nieuchronne przemiany biologiczne, ale również starać się je w miarę możliwości opóźniać poprzez prawidłowy styl życia $[3,4]$.

Proces starzenia się jest nieuchronny i nieodwracalny, istotną rzeczą jest przestrzeganie zasad profilaktyki zdrowotnej i społecznej. Pomimo szerokiego dostępu do edukacji zdrowotnej, małej liczbie osób udaje się dożyć do sędziwego wieku, zazwyczaj wynika to z błędów popełnianych w młodości. Należy jednak pamiętać, iż nigdy nie jest za późno na dokonanie zmian w swoim codziennym życiu i poprawie jego jakości [5]

Wśród najważniejszych osób, które mają wpływ na przestrzeganie zdrowego stylu życia wśród osób starszych są przede wszystkim rodzina, najblizszze otoczenie oraz pracownicy ochrony zdrowia. Zdarza się, że seniorzy nie przestrzegają prozdrowotnych zachowań. Bierze się to stąd, iż mają złe nawyki z młodości, nie posiadają odpowiedniej wiedzy, brakuje im wzorców do naśladowania. Pracownicy służby zdrowia są uważani za najbardziej wiarygodne i kompetentne osoby, które promują zdrowie w społeczeństwie, dlatego istotne znaczenie w promocji zdrowia u osób starszych odgrywa rola pielęgniarki. Jej zadania powinny skupiać się zarówno na działaniach profilaktycznych, jak i edukacji zdrowotnej. Podczas edukacji pacjenta pielęgniarka powinna zwrócić uwagę na takie aspekty, jak zdrowie, aktywność fizyczna, racjonalne odżywianie, odpowiedni odpoczynek, prawidłowy sen oraz umiejętność radzenia sobie w sytuacjach stresowych $[6,7]$.

Celem pracy była analiza zachowań zdrowotnych osób starszych w powiecie dębickim.

\section{Materiał i metody}

Badania przeprowadzono wśród losowo wybranych mieszkańców powiatu dębickiego, w okresie dwóch miesięcy od marca do kwietnia 2016 r. Badaną populację stanowiły osoby, które wyraziły zgodę na badanie, a także byli zdolni do czytania, pisania i samodzielnego wypełnienia kwestionariusza. Rozdawano kwestionariusze ankiety, tłumacząc, wjaki sposób należy go wypełnić. Respondenci biorący udział w badaniach zostali poinformowani o anonimowości, celu badań, prawie do odmowy udziału w badaniu lub do wycofania zgody na udział $w$ badaniu $w$ dowolnym czasie, bez żadnych konsekwencji. Po wyrażeniu świadomej zgody samodzielnie wypełniali kwestionariusze ankiet. Wskaźnik zwrotności ankiet wyniósł 100\%. Zasadnicze badania poprzedzono badaniem pilotażowym $w$ grupie studentów II roku studiów stacjonarnych magisterskich w ilości kilku egzemplarzy.

W pracy posłużono się metodą sondażu diagnostycznego, narzędziem był autorski kwestionariusz ankiety oraz Inwentarz Zachowań Zdrowotnych Z. Juczyńskiego.

Kwestionariusz ankiety zawierał 10 pytań, które obejmowały czynniki społeczno-demograficzne, stan zdrowia oraz styl życia.

Inwentarz Zachowań Zdrowotnych (IZZ) zawiera 25 różnych stwierdzeń związanych ze zdrowiem. W metodzie tej bierze się pod uwagę wskazaną przez grupę badanych częstotliwość poszczególnych zachowań, następnie ustala się nasilenie zachowań pozytywnych dla zdrowia oraz stopień nasilenia czterech kategorii zachowań zdrowotnych. Do tych kategorii należą: prawidłowe nawyki żywieniowe, praktyki zdrowotne, zachowania profilaktyczne oraz pozytywne nastawienie psychiczne. Prawidłowe nawyki żywieniowe określają rodzaj zjadanej żywności, np.: owoce, warzywa, pełnoziarniste pieczywo. Praktyki zdrowotne obejmują nawyki dotyczące snu, rekreacji lub aktywności fizycznej. Zachowania profilaktyczne obejmują przestrzegania zaleceń zdrowotnych oraz uzyskiwania informacji na temat zdrowia i choroby. Natomiast pozytywne nastawienie psychiczne są to czynniki psychologiczne, pozwalające określić, jak badany unika zbyt silnych emocji, stresów, a także sytuacji wpływających przygnębiająco. W inwentarzu zachowań zdrowotnych osoba badana określa, jak często przestrzega zachowań związanych ze zdrowiem, dzięki pięciostopniowej skali. Następnie uzyskane wartości liczbowe zaznaczone przez badanych sumuje się dla uzyskania ogólnego wskaźnika zachowań zdrowotnych. Wartość IZZ mieści się między 24 a 120 punktów. Im wynik jest wyższy, tym większe jest nasilenie deklarowanych zachowań zdrowotnych. Za wynik niski traktuje się wynik 1-4 stena, w granicach 5-6 jako przeciętny, jako wysoki wynik traktuje się 7-10 sten [8].

Weryfikacji różnic między zmiennymi dokonano testem Manna-Whitneya oraz testem Kruskala-Wallisa. Przyjęto poziom istotności $p<0,05$. Obliczenia przeprowadzono programem SPSS. 


\section{Wyniki}

W badaniu wzięło udział 140 osób w przedziale wiekowym od 65 do 82 lat. Średnia wieku badanych to 72,57 lat $(S D=5,14)$. Wiek badanych wahał się od 65 lat do 82 lat. W grupie wiekowej $65-70$ lat znalazło się $42,1 \%$ osób. Od 71 do 75 lat miało $24,3 \%$ badanych, a $76-82$ lata 33,6\% osób. W badanej grupie znalazło się nieznacznie więcej kobiet $(54,3 \%)$ niż mężczyzn $(45,7 \%)$. Połowa badanych mieszkała na wsi, a połowa $w$ mieście. Wykształcenie podstawowe posiadało $8,6 \%$ osób. Wykształceniem średnim wykazało się 35,0\% badanych. Wykształcenie zawodowe miało 42,1\% osób, a wykształcenie wyższe 14,3\% badanych. Niemal połowa osób (49,3\%) pozostawała w związku małżeńskim. Wdowy/wdowcy stanowili 31,4\% osób, a osoby stanu wolnego 15,0\% badanych. Nieliczne osoby $(4,3 \%)$ były po rozwodzie. Większość osób (72,1\%) mieszkała z najbliższą rodziną (mężem, żoną, dziećmi). Samotnie mieszkało 21,4\% osób, a z dalszą rodziną $6,4 \%$ badanych. Bardzo dobry status materialny miało $14,3 \%$ osób. Dobry status materialny - 29,3\% osób, a zadowalający - 47,9\% badanych. Posiadanie złego statusu materialnego zadeklarowało 8,6\% osób.

W pełni sprawnymi było $46 \%$ osób. Nieznacznej pomocy tylko w niektórych czynnościach, które wymagają dużego wysiłku, potrzebowało 43\% osób. Stałej opieki i pomocy w codziennych czynnościach potrzebowało $11 \%$ badanych (Rycina 1).
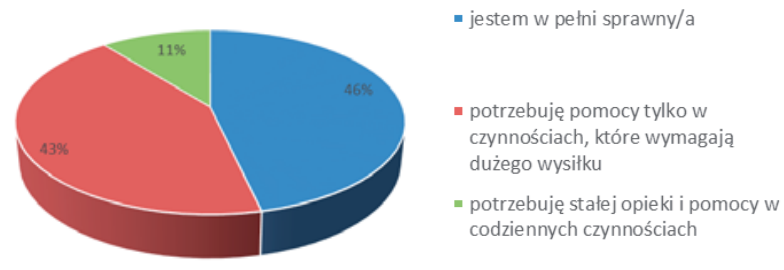

Rycina 1. Samoocena aktualnego stanu zdrowia badanych

Grupa 43\% osób starała się przestrzegać zdrowego stylu życia. Nie przestrzegało zasad zdrowego stylu życia 13\% badanych. Dla 22\% osób zdrowy styl życia był obojętny. Tyle samo badanych wiedziało, na czym polega zdrowy styl życia (Rycina 2).
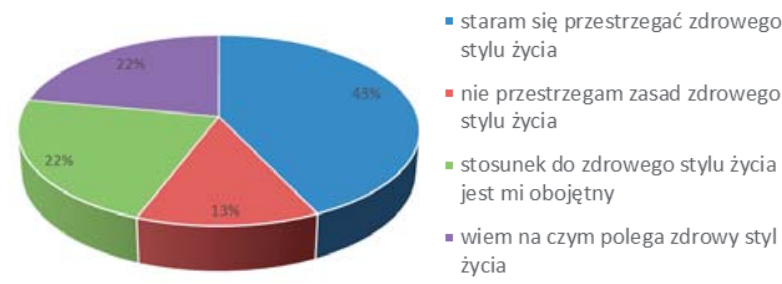

Rycina 2. Stosunek do zdrowego stylu życia
Wśród preferowanych form spędzania czasu wolnego badani najczęściej wymieniali spacery (38\%). W mniejszym stopniu w czasie wolnym czytali lub oglądali telewizję (19\%). Grupa 16\% osób preferowała w czasie wolnym sen i odpoczynek. Spotkania ze znajomymi w czasie wolnym wybierało 14\% osób, a sport 13\% badanych (Rycina 3).

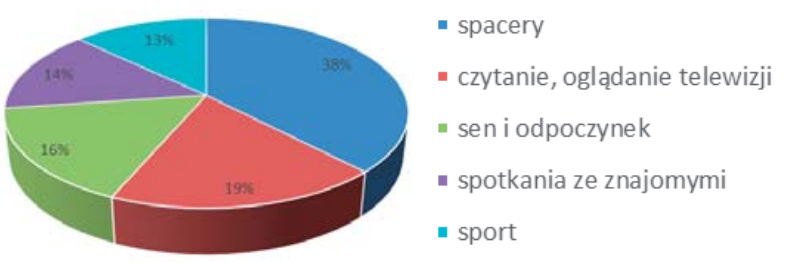

Rycina 3. Preferowane formy spędzania czasu wolnego

Średni poziom nasilenia zachowań zdrowotnych wyniósł 86,89 pkt. ( $S D=12,32)$ na skali 24-120 pkt. Wyniki wahały się od 58 pkt. do 114 pkt. i był istotnie wyższy od wartości odpowiadające połowie skali, tj. 72 pkt. $(p<0,0001)$. Na tej podstawie można stwierdzić, że nasilenie zachowań zdrowotnych wśród badanych było powyżej poziomu przeciętnego.

W przypadku 4 kategorii zachowań zdrowotnych najlepsze wyniki (skala 1-5 pkt.) badani osiągnęli w przypadku zachowań profilaktycznych (3,91 pkt.). Nieznacznie niżej ocenione zostało pozytywne nastawienie psychiczne (3,70 pkt.). Średni poziom praktyk zdrowotnych wyniósł 3,49 pkt. $(S D=0,56)$, a prawidłowych nawyków żywieniowych 3,38 pkt. (SD =0,69) (Tabela 1).

Tabela 1. Nasilenie zachowań zdrowotnych wśród badanych

\begin{tabular}{|l|c|c|c|c|c|} 
Średnia & $\begin{array}{c}\text { Nasilenie } \\
\text { zachowań } \\
\text { zdrowotnych }\end{array}$ & $\begin{array}{c}\text { Prawidłowe } \\
\text { nawyki } \\
\text { żyieniowe }\end{array}$ & $\begin{array}{c}\text { Zachowania } \\
\text { profilaktyczne }\end{array}$ & $\begin{array}{c}\text { Pozytywne } \\
\text { nastawienia } \\
\text { psychiczne }\end{array}$ & $\begin{array}{c}\text { Praktyki } \\
\text { zdrowotne }\end{array}$ \\
SD & 12,89 & 3,38 & 3,91 & 3,70 & 3,49 \\
Minimum & 58 & 1,67 & 1,67 & 2,67 & 2,17 \\
Maksimum & 114 & 4,83 & 5,00 & 4,83 & 4,83
\end{tabular}

Stwierdzono, że kobiety prezentowały istotnie wyższe nasilenie zachowań profilaktycznych $(3,97)$ niż mężczyźni $(3,85)$. Również wśród kobiet wyżej plasowały się praktyki zdrowotne $(3,60)$ niż u mężczyzn $(3,35)$. Nie stwierdzono, by płeć badanych istotnie wpływała na inne zachowania zdrowotne (Tabela 2). 
Tabela 2. Nasilenie zachowań zdrowotnych a płeć badanych

\begin{tabular}{|l|c|c|c|c|c|c|}
\multicolumn{1}{|c|}{ Płeć } & $\begin{array}{c}\text { Nasilenie } \\
\text { zachowań } \\
\text { zdrowotnych }\end{array}$ & $\begin{array}{c}\text { Prawidłowe } \\
\text { nawyki } \\
\text { żywieniowe }\end{array}$ & $\begin{array}{c}\text { Zachowania } \\
\text { profilaktyczne }\end{array}$ & $\begin{array}{c}\text { Pozytywne } \\
\text { nastawienia } \\
\text { psychiczne }\end{array}$ & $\begin{array}{c}\text { Praktyki } \\
\text { zdrowotne }\end{array}$ \\
Kobieta & Średnia & 88,32 & 3,46 & 3,97 & 3,70 & 3,60 \\
Sęż- & 11,74 & 0,67 & 0,61 & 0,54 & 0,46 \\
Czyzna & Średnia & 85,19 & 3,28 & 3,85 & 3,72 & 3,35 \\
Ogółem & 12,86 & 0,70 & 0,50 & 0,64 & 0,65 \\
& Średnia & 86,89 & 3,38 & 3,91 & 3,70 & 3,49 \\
PD & 12,32 & 0,69 & 0,56 & 0,59 & 0,56 \\
P & 0,1321 & 0,1262 & 0,0151 & 0,6891 & 0,0316
\end{tabular}

Nie stwierdzono, by wiek badanych istotnie wpływał na nasilenie zachowań zdrowotnych, zarówno w wyniku ogólnym, jak i poszczególnych kategoriach $(p>0,05)$.

Wyższy poziom nasilenia zachowań zdrowotnych mieli mieszkańcy miast (89,87 pkt.), a niższy mieszkańcy wsi (83,90 pkt.). Wynikało to z wyższych wyników związanych z praktykami zdrowotnymi wśród mieszkańców miast $(3,69)$ niż wśród mieszkańców wsi $(3,28)$. W mniejszym, ale istotnych stopniu różnice te dotyczyły również zachowań profilaktycznych, które wyższe były u mieszkańców miast $(4,02)$ niż u mieszkańców wsi $(3,80)$. Nieznaczne różnice sugerowały również wyższe prawidłowe nawyki żywieniowe u mieszkańców miast, niż u mieszkańców wsi (Tabela 3).

Tabela 3. Nasilenie zachowań zdrowotnych a miejsce zamieszkania badanych

\begin{tabular}{|c|c|c|c|c|c|c|}
\hline $\begin{array}{l}\text { Mie } \\
\text { zamies }\end{array}$ & $\begin{array}{l}\text { jsce } \\
\text { szkania }\end{array}$ & $\begin{array}{c}\text { Nasilenie } \\
\text { zachowań } \\
\text { zdrowotnych }\end{array}$ & $\begin{array}{c}\text { Prawidłowe } \\
\text { nawyki } \\
\text { żywieniowe }\end{array}$ & $\begin{array}{l}\text { Zachowania } \\
\text { profilaktyczne }\end{array}$ & $\begin{array}{l}\text { Pozytywne } \\
\text { nastawienia } \\
\text { psychiczne }\end{array}$ & $\begin{array}{l}\text { Praktyki } \\
\text { zdrowotne }\end{array}$ \\
\hline & Średnia & 89,87 & 3,47 & 4,02 & 3,79 & 3,69 \\
\hline Mlasto & SD & 10,15 & 0,68 & 0,42 & 0,49 & 0,45 \\
\hline & Średnia & 83,90 & 3,28 & 3,80 & 3,62 & 3,28 \\
\hline Wieś & SD & 13,59 & 0,69 & 0,66 & 0,66 & 0,59 \\
\hline Orótrm & Średnia & 86,89 & 3,38 & 3,91 & 3,70 & 3,49 \\
\hline ogotem & SD & 12,32 & 0,69 & 0,56 & 0,59 & 0,56 \\
\hline p & o & 0,0104 & 0,0758 & 0,0493 & 0,1027 & 0,0001 \\
\hline
\end{tabular}

Stwierdzono, że nasilenie zachowań zdrowotnych wzrastało istotnie wraz z poziomem wykształcenia badanych. Najwyższe nasilenie zachowań zdrowotnych miały osoby z wykształceniem wyższym (91,95 pkt.). Niższe nasilenie zachowań zdrowotnych stwierdzono u osób z wykształceniem średnim (88,49 pkt.). Jeszcze niższe (85,53 pkt.) nasilenie zachowań zdrowotnych miały osoby z wykształceniem zawodowym, a najniższe badani z wykształceniem podstawowym (78,58 pkt.). Relacja ta przekładała się istotnie na zachowania profilaktyczne i praktyki zdrowotne - wraz z poziomem wykształcenia badanych wzrastały te zachowania zdrowotne. Na granicy poziomu istotności była relacja w przypadku pozytywnego nastawienia psychicznego, gdzie najwyższe wyniki miały osoby $z$ wykształceniem wyższym $(3,85)$, a najniższe osoby z wykształceniem podstawowym $(3,24)$ (Tabela 4).

Tabela 4. Nasilenie zachowań zdrowotnych a wykształcenie badanych

\begin{tabular}{|c|c|c|c|c|c|c|}
\hline \multicolumn{2}{|c|}{ Wykształcenie } & $\begin{array}{c}\text { Nasilenie } \\
\text { zachowań } \\
\text { zdrowotnycl }\end{array}$ & $\begin{array}{c}\text { Prawidłowe } \\
\text { nawyki } \\
\text { żywieniowe }\end{array}$ & $\begin{array}{l}\text { Zachowania } \\
\text { profilaktyczne }\end{array}$ & $\begin{array}{l}\text { Pozytywne } \\
\text { nastawienia } \\
\text { psychiczne }\end{array}$ & $\begin{array}{c}\text { Praktyki } \\
\text { zdrowotne }\end{array}$ \\
\hline \multirow{2}{*}{$\begin{array}{l}\text { Podsta- } \\
\text { wowe }\end{array}$} & Średnia & 78,58 & 3,11 & 3,64 & 3,24 & 3,11 \\
\hline & SD & 14,49 & 0,71 & 0,53 & 0,86 & 0,51 \\
\hline \multirow{2}{*}{ Średnie } & Średnia & 88,49 & 3,44 & 3,93 & 3,71 & 3,67 \\
\hline & SD & 12,17 & 0,73 & 0,70 & 0,45 & 0,47 \\
\hline \multirow{2}{*}{$\begin{array}{l}\text { Zawo- } \\
\text { dowe }\end{array}$} & Średnia & 85,53 & 3,31 & 3,90 & 3,75 & 3,30 \\
\hline & SD & 11,57 & 0,60 & 0,46 & 0,62 & 0,54 \\
\hline \multirow{2}{*}{ Wyższe } & Średnia & 91,95 & 3,57 & 4,09 & 3,85 & 3,82 \\
\hline & SD & 11,10 & 0,79 & 0,40 & 0,46 & 0,56 \\
\hline \multirow{2}{*}{ Ogółem } & Średnia & 86,89 & 3,38 & 3,91 & 3,70 & 3,49 \\
\hline & SD & 12,32 & 0,6 & 0,56 & 0,59 & 0,56 \\
\hline \multicolumn{2}{|l|}{$p$} & 0,0191 & 0,1138 & 0,0353 & 0,0556 & $<0,0001$ \\
\hline
\end{tabular}

Nie stwierdzono, by nasilenie zachowań zdrowotnych zależało istotnie od stanu cywilnego badanych $(p>0,05)$.

Badania własne wykazały, że niższe nasilenie pozytywnego nastawienia psychicznego miały osoby mieszkające samotnie (3,43 pkt.). Wyższe wyniki w tej kategorii uzyskały osoby mieszkające z najbliższą rodziną (3,78 pkt.) lub z dalszą rodziną $(3,74$ pkt.) $(p<0,0109)$. Nie stwierdzono, by sposób mieszkania różnicował istotnie inne kategorie zachowań zdrowotnych oraz ogólne nasilenie zachowań zdrowotnych.

Nieznaczne różnice wskazywały, że osoby z zadowalającym statusem materialnym (4,04 pkt.) miały wyższe wyniki związane z zachowaniami profilaktycznymi niż inni badani ( $p<0,0447)$. Niewielkie różnice sugerowały również, że wraz ze spadkiem statusu materialnego zmniejszało się pozytywne nastawienie psychiczne badanych. Nie stwierdzono, by status materialny istotnie wpływał na inne zachowania zdrowotne.

Zachowania zdrowotne badanych zależały istotnie od stosunku do zdrowego stylu życia. Osoby starające się przestrzegać zdrowotnego stylu życia miały istotnie wyższy ogólny wskaźnik nasilenia zachowań zdrowotnych (96,03 pkt.), oraz wyniki w poszczególnych kategoriach, w porównaniu do pozostałych osób. Niżej w kolejności zachowań zdrowotnych uplasowały się osoby, które miały obojętny stosunek do zdrowego stylu życia lub wiedziały, na czym on polega. Najniższe wyniki osiągnęły osoby, które nie przestrzegały zasad zdrowego stylu życia (Tabela 5). 
Tabela 5. Nasilenie zachowań zdrowotnych a stosunek do zdrowego stylu życia

\begin{tabular}{|c|c|c|c|c|c|c|}
\hline \multicolumn{2}{|c|}{$\begin{array}{l}\text { Stosunek } \\
\text { do zdrowego } \\
\text { stylu życia }\end{array}$} & $\begin{array}{c}\text { Nasilenie } \\
\text { zachowań } \\
\text { zdrowotnych }\end{array}$ & $\begin{array}{c}\text { Prawidłowe } \\
\text { nawyki } \\
\text { żywieniowe }\end{array}$ & $\begin{array}{c}\text { Zachowania } \\
\text { profilaktyczne }\end{array}$ & $\begin{array}{l}\text { Pozytywne } \\
\text { nastawienia } \\
\text { psychiczne }\end{array}$ & $\begin{array}{c}\text { Praktyki } \\
\text { zdrowotne }\end{array}$ \\
\hline $\begin{array}{l}\text { staram się } \\
\text { prze- } \\
\text { strzegać } \\
\text { zdrowego } \\
\text { stylu życia }\end{array}$ & $\mid \begin{array}{c}\text { Średnia } \\
\text { SD }\end{array}$ & 96,03 & 3,92 & 4,29 & 3,96 & 3,84 \\
\hline $\begin{array}{l}\text { nie prze- } \\
\text { strzegam } \\
\text { zasad } \\
\text { zdrowego } \\
\text { stylu życia }\end{array}$ & $\begin{array}{c}\text { Średnia } \\
\text { SD }\end{array}$ & 72,11 & 2,48 & 3,21 & 3,19 & 3,13 \\
\hline \multirow{4}{*}{$\begin{array}{l}\text { stosunek } \\
\text { do } \\
\text { zdrowego } \\
\text { stylu życia } \\
\text { jest mi } \\
\text { obojętny } \\
\text { wiem na } \\
\text { czym } \\
\text { polega } \\
\text { zdrowy } \\
\text { styl } \\
\text { życia }\end{array}$} & Średnia & 84,42 & 3,27 & 3,87 & 3,63 & 3,30 \\
\hline & & & & & & \\
\hline & Średnia & 80,23 & 2,95 & 3,65 & 3,58 & 3,20 \\
\hline & SD & 11,95 & 0,49 & 0,46 & 0,71 & 0,61 \\
\hline \multirow{2}{*}{ Ogółem } & Średnia & 86,89 & 3,38 & 3,91 & 3,70 & 3,49 \\
\hline & SD & 12,32 & 0,69 & 0,56 & 0,59 & 0,56 \\
\hline \multicolumn{2}{|l|}{ P } & $<0,0001$ & $<0,0001$ & $<0,0001$ & $<0,0001$ & $<0,0001$ \\
\hline
\end{tabular}

Badania własne wykazały, że osoby preferujące w wolnym czasie czytanie lub oglądanie telewizji 3,69 pkt.) miały istotnie niższe nasilenie prawidłowych nawy-

$14^{2}$ ków żywieniowych niż pozostali badani $(p<0,0201)$. Nieznaczne różnice sugerowały wyższe nasilenia zachowań profilaktycznych oraz pozytywnego nastawienia psychicznego u osób, które preferowały sport lub spacery.

\section{Dyskusja}

Zdrowie każdego człowieka zależy w dużej mierze od indywidualnych zachowań zdrowotnych człowieka, które pozwalają go utrzymywać, przywracać, a także potęgować. Zachowania zdrowotne definiowane są jako wszystkie czynności, które zmierzają do utrzymywania zdrowia lub do jego powrotu. Problem jakości i stylu życia osób starszych w ostatnich latach jest przedmiotem zainteresowania społecznego. Funkcjonowanie osób, które przekroczyły 60 rok życia niejednokrotnie staje się tematem wielu analiz badawczych, ponieważ w wyniku procesów demograficznych średnia długość życia ulega wydłużeniu i rośnie liczba osób w wieku starszym [3].

Przeprowadzone badania miały na celu analizę zachowań zdrowotnych osób starszych w powiecie dębickim. W badaniu wzięło udział 140 mieszkańców powiatu dębickiego w przedziale wiekowym od 65 do 85 lat.

Badania własne wykazały, że nasilenie zachowań zdrowotnych wśród badanych osób było powyżej poziomu przeciętnego. Średni poziom nasilenia zachowań zdrowotnych wyniósł 86,89 pkt. Wśród czterech kategorii zachowań zdrowotnych na najwyższej pozycji znalazły się zachowania profilaktyczne (3,91 pkt.), nieznacznie niżej ocenione zostało pozytywne nastawienie psychiczne (3,70 pkt.). Następnie znalazły się praktyki zdrowotne, które stanowiły 3,94 pkt. oraz prawidłowe nawyki żywieniowe (3,38 pkt.). Nieco inne wyniki uzyskali w swoich badaniach Kupcewicz i wsp. Według nich najwyższy wskaźnik zachowań zdrowotnych zaobserwowano w kategorii pozytywnej postawy psychicznej $(3,61 \pm 0,79)$, kolejno znajdowały się właściwe nawyki żywieniowe $(3,24 \pm 1,03)$, zachowania profilaktyczne $(3,23 \pm 1,12)$ i praktyki zdrowotne $(3,22$ $\pm 1,02$ ) [9]. Badania przeprowadzone pośród studentów Uniwersytetu III wieku przy PWSZ im. Jana Grodka w Sanoku, których celem również była analiza zachowań zdrowotnych osób starszych, wykazały wysoki średni wynik zachowań zdrowotnych. Wynosił on 88,39 pkt. $Z$ badań przeprowadzonych przez Smoleń, Gazdowic, Żyłka-Reut wynika, iż osoby starsze to grupa, która cechuje się wysokim poziomem zachowań zdrowotnych w zakresie prawidłowych nawyków żywieniowych oraz zachowań profilaktycznych, jak również praktyk zdrowotnych i pozytywnego nastawienia psychicznego [10]. Również w badaniach przeprowadzonych przez Muszalik iZielińską-Więczkowską wykazano dość wysoki poziom zachowań zdrowotnych wśród osób starszych, u autorów wynosił on 83,2 pkt. Prawidłowe zachowania zdrowotne wpływają na postawę wobec zdrowia, którą można nabyć w ciągu całego życia. $Z$ analizowanych badań wynika, że najwyższe wyniki uzyskano w kategorii zachowań profilaktycznych, pozytywnego nastawienia psychicznego, a także praktyk zdrowotnych, a najniższe dotyczyły prawidłowych praktyk żywieniowych. W tym przypadku pokrywają się one z badaniami własnym [11]. Badania przeprowadzone przez Kozieł i wsp. wskazały, że ludzie starsi, aktywni intelektualnie prezentowali ogólnie wyższy wskaźnik zachowań prozdrowotnych, mieli lepsze nawyki żywieniowe, częściej podejmowali zachowania profilaktyczne i praktyki służące zdrowiu, wykazywali bardziej pozytywne nastawienie psychiczne w porównaniu z ich rówieśnikami z grupy kontroInej [12]. Badania Tańskiej i wsp. wykazują, że zdecydowana większość - 94.4\% słuchaczy Uniwersytetu Trzeciego Wieku w Słupsku zadeklarowała, iż dba o swoją dietę [13].

W badaniach własnych wykazano, że kobiety prezentowały wyższe nasilenie zachowań profilaktycznych $(3,97$ pkt.) i praktyk zdrowotnych $(3,60)$ niż mężczyźni. Nie stwierdzono związku pomiędzy płcią badanych, a innymi zachowaniami zdrowotnymi. Wyższy poziom nasilenia zachowań zdrowotnych zaobserwowano u mieszkańców miast, stanowili oni 87,89 pkt. Nie wykazano natomiast 
związku pomiędzy wiekiem, a poziomem nasilenia zachowań zdrowotnych. Biorąc pod uwagę analizę zachowań zdrowotnych osób w wieku senioralnym Zadwornej -Cieślak i Ogińskiej-Bulik można stwierdzić, że seniorzy prezentują wyższy niż przeciętny poziom podejmowanych zachowań zdrowotnych. Jak wynika zarówno z badań własnych, jak i tych prezentowanych przez autorki, płeć jest związana z nasileniem zachowań zdrowotnych, gdyż to właśnie kobiety prezentują wyższe wyniki zarówno w kategorii zachowań profilaktycznych, nawyków żywieniowych, jak i praktyk zdrowotnych. Wykazano również, że wiek nie ma istotnego wpływu na przestrzeganie zachowań zdrowotnych [3].

Stwierdzono jednocześnie, że wraz ze wzrostem poziomu wykształcenia wśród badanej grupy wzrastał poziom nasilenia zachowań zdrowotnych, najwyższy poziom zachowań zdrowotnych miały osoby z wykształceniem wyższym (91,95 pkt.), natomiast najniższy badani z wykształceniem podstawowym (78,58 pkt.). W analizie Smoleń, Gazdowicz, Żyłka-Reut wyodrębniono wykształcenie jako wyznacznik pozycji społecznej, który odzwierciedla poziom wiedzy, w tym wiedzy medycznej. Istnieje zależność między poziomem wykształcenia, a lepszym stanem zdrowia i większą sprawnością. Wśród badanych $46 \%$ posiadało średnie wykształcenie, $25 \%$ wyższe, było to wyznacznikiem aktywności, a zarazem chęci poszerzania swojej wiedzy po przez udział w zajęciach UTW [10]. Sygit-Kowalkowska w swoich badaniach analizowała związek pomiędzy poszczególnymi kategoriami zachowań zdrowotnych osób w wieku starszym, a zmiennymi społeczno-demograficznymi. Pod uwagę wzięto m.in. wiek, płeć, wykształcenie oraz przynależność do środowiska Uniwersytetu Trzeciego Wieku lub środowiska pomocy społecznej. W badaniu wzięło udział 199 osób po 60 roku życia, którzy mieszkali w Bydgoszczy i Toruniu. Jak wykazały badania, tylko wykształcenie badanych osób wpływa na wskaźnik zachowań zdrowotnych, m.in. pozytywne nastawienie psychiczne pozostaje w istotnym związku w wykształceniem; wraz z podnoszeniem się wyniku wykształcenia rośnie poziom nasilenia zachowań zdrowotnych [14]. W analizie Muszalik, Zielińskiej-Więczkowskiej także stwierdzono wpływ wykształcenia na praktyki zdrowotne, gdyż u osób z wyższym wykształceniem zanotowano istotnie wyższy poziom praktyk zdrowotnych [11].

$Z$ badań własnych wynika, że pozytywne nastawienie psychiczne najniżej oceniane było u osób mieszkających samotnie (3,43 pkt.), wyższe wyniki w tej kategorii prezentowały osoby mieszkające $z$ najbliższa rodziną $(3,78$ pkt.), a także z dalszą rodziną (3,74 pkt). Nie wykazano, aby sposób mieszkania badanych wpływał istotnie na inne kategorie zachowań zdrowotnych. Według autorów do wytycznych pozytywnego nastawienia psychicznego zaliczano m.in. poważne traktowanie wskazówek osób, które są zaniepokojone stanem zdrowia, unikanie sytuacji wypływających przygnębiająco, a także unikanie silnych emocji i napięć oraz uregulowane życie rodzinne. Badana grupa deklarowała znacznie podwyższone wartości dotyczące zarówno uregulowane życia rodzinnego (4,10 pkt.), jak i unikania silnych emocji i napięć (3,42 pkt.) [10].

Podsumowując można stwierdzić, że osoby starsze należą do grupy osób, której styl życia i wskaźnik podejmowanych zachowań zdrowotnych powinny służyć jako wzór dla innych społeczności. Cechują się oni nie tylko bogatym doświadczeniem życiowym, ale także prozdrowotnym nastawieniem, które służy utrzymywaniu i umacnianiu zdrowia.

\section{Wnioski}

1. Najbardziej nasilone u osób starszych są zachowania profilaktyczne, następnie pozytywne nastawienie psychiczne i praktyki zdrowotne, a najmniej praktyki żywieniowe.

2. Osoby z wyższym wykształceniem, kobiety oraz osoby mieszkające w mieście prezentują wyższy poziom nasilenia zachowań zdrowotnych niż osoby z wykształceniem podstawowym.

3. Wiek badanych nie ma wpływu na przestrzeganie zachowań zdrowotnych.

4. Status materialny ma istotny wpływ na zachowania profilaktyczne i pozytywne nastawienie psychiczne osób badanych.

5. Osoby starające się przestrzegać zdrowego stylu życia, w tym także zasad prawidłowego żywienia mają wyższy wskaźnik nasilenia zachowań zdrowotnych.

\section{Oświadczenia}

Oświadczenie dotyczące konfliktu interesów

Autorzy deklarują brak konfliktu interesów.

\section{Źródła finansowania}

Autorzy deklarują brak źródeł finansowania.

\section{Piśmiennictwo}

1. Zielińska-Więczkowska H, Kędziora-Kornatowska K, Kornatowski T. Starość jako wyzwanie. Gerontologia Polska 2008; 16(3), 131-136.

2. Młynarska M, Rudnicka-Drożak E. Pojęcie zdrowia w opinii osób powyżej 65 roku życia. Gerontologia Polska 2015; 1: 11-18.

3. Bulik N, Cieślak M. Zachowania zdrowotne osób w wieku senioralnym - rola optymizmu. Psychogeriatria Polska 2013, 10(4): 145-156.

4. Muszalik M, Kędziora-Kornatowska K. The analysis healthy behavior among elderly people in Juczyński's Inventory of 
Healthy Behavior. Advences In Medical Sciences 2007; 52(1) 105-107.

5. Janiszewska M, Kulik T, Żołnierczuk-Kieliszek D. Wartościowanie zdrowia wśród osób starszych na przykładzie studentów uniwersytetu trzeciego wieku. Pielęgniarstwo Polskie 2016; 1(59), 49-55.

6. Andruszkiewicz A, Banaszkiewicz M. Zachowania zdrowotne, [w:] Promocja zdrowia dla studentów studiów licencjackich pielęgniarstwa i położnictwa; tom 1, wyd. Czelej, Lublin 2008: 70-82.

7. Żołnierczuk-Kieliszek D. Zachowania zdrowotne i ich związek ze zdrowiem, [w:] Zdrowie Publiczne. Podręcznik dla studentów i absolwentów wydziałów pielęgniarstwa i nauk o zdrowiu akademii medycznych; wyd. Czelej, Lublin 2002: 75-114.

8. Juczyński Z. Narzędzia pomiaru w promocji i psychologii zdrowia, wyd. Pracownia Testów Psychologicznych Polskiego Towarzystwa Psychologicznego, Warszawa 2001: 117-122.

9. Kupcewicz E, Gontarz A, Wilk B, Kuśmierczyk M. Evaluation of health behaviours of individuals aged over 60 years. Hygeia Public Health 2016, 51(2): 202-208.

10. Smoleń E, Gazdowicz L, Żyłka-Reut A. Zachowania zdrowotne osób starszych. Pielęgniarstwo XXI wieku 2011, 3(36): 5-9.

11. Muszalik M, Zielińska-Więczkowska H. Ocena wybranych zachowań sprzyjających zdrowiu wśród osób starszych w oparciu o Inwentarz Zachowań Zdrowotnych Juczyńskiego w aspekcie czynników socjo-demograficznych. Problemy Higieny i Epidemiologii 2013; 94(3): 509-513.

12. Kozieł D, Kaczmarczyk M, Naszydłowska E, Gałuszka R. Wpływ kształcenia w uniwersytecie trzeciego wieku na zachowania zdrowotne ludzi starszych. Studia Medyczne 2008; 12: 23-28.

13. Tańska M, Babicz-Zielińska E, Przysławski J. Postawy osób starszych wobec zdrowia i żywności o działaniu prozdrowotnym. Probl Hig Epidemiol 2013, 94(4): 915-918.

14. Sygit-Kowalkowska E. Zachowania zdrowotne osób w okresie późnej dorosłości - socjodemograficzne korelaty i różnice między środowiskami społecznymi. Roczniki Pomorskiej Akademii Medycznej w Szczecinie 2013; 59(1), 103-113.

Zaakceptowano do edycji: 20.08.19 Zaakceptowano do publikacji: 26.09.19
Adres do korespondencji:

Aneta Grochowska

PWSZ w Tarnowie

ul. Mickiewicza 8

33-100 Tarnów

tel. 146310751

e-mail: grochowskaaneta@o2.p 